\title{
URBAN SCIENCE BETWEEN TRANSPARENT MANAGEMENT AND CORPORATE APPROPRIATION: A study concerning systems of urban assessment
}

\section{CIÊNCIA URBANA ENTRE A GESTÃO TRANSPARENTE E APROPRIAÇÃO CORPORATIVA: Um estudo sobre sistemas de avaliação urbana}

\author{
A. Raphael Grazziano \\ University of São Paulo, Brazil \\ raphael.grazziano@gmail.com
}

\begin{abstract}
Urban science is the planning branch that uses large scale data to establish new ways to govern cities, being systems of urban assessment an example of its contemporary manifestation. What Works Cities (WWC) from Bloomberg Philanthropies and Leadership in Energy and Environmental Design for Cities and Communities (LEEDC CC) from US Green Building Council are examples of such systems, the first dealing with data management and the latter with environmental sustainability. This paper aims to assess how these systems affect urban policy by means of their evaluation methods. Both systems are presented and their certifications geolocated. It is argued that these systems focus on process, and not results, leading to an ambivalent set of certifications. At last, it is suggested that the same transparency promoted by these systems in their candidates' assessment should be applied to themselves, in order to guarantee the adequacy of their certifications.
\end{abstract}

Keywords: smart cities, urban planning, LEED@ for cities and communities, what works cities.

Thematic clusters: 1 . City and project.

Topic: Planning, policies and governance. 


\section{SÃOPAULO15 $\quad 17 \cdot$ LISBOA $25 \sim 26$ JUN 2020}

\section{Introduction}

This ongoing research deals with spatial phenomena promoted by organizations, rather than more traditionally studied agents linked to the market or the state. These organizations are deeply related to both of these agents and can share with the market and the state activities as well as ideologies, even if they hold sociological specificities.

Organizations are social practices determined by private means and goals. As such, they are conducted by ideas of management, planning, prevision, control, and success, and do not question their own social role, as an institution would do. An organization works to achieve an outcome, instead of the institutional insertion in the social fabric (Chauí, 2003). The relevance of organizations in the social practices is not new: since the beginning of the 1990s, they are central agents in the political arena and in academic research (Beck, 2005, ch. 6; Boli \& Thomas, 1999; Castells, 2010). However, there are few studies about their involvement in the production of space.

The paper will analyze two systems of urban assessment promoted by organizations. Both rely deeply in large scale data collection as a way to better manage cities. On the one hand, the certification What Works Cities (WWC), created by Bloomberg Philanthropies to subsidize plans for better management in North American mid-sized cities. On the other, Leadership in Energy and Environmental Design for Cities and Communities (LEEDC CC), a system of urban assessment created by the NGO United States Green Building Council (USGBCC), dedicated to the environmental sustainability in the building sector.

As such, this paper develops a research previously carried out about the history of USGBC@ and the impact of LEEDC in the design of buildings (Grazziano, 2019). This is done by expanding the scope of LEEDC systems: while the previous research was dedicated to LEEDC Core \& Shell (for speculative buildings) and Neighborhood Development, this work studies LEEDC CC, a distinct certification system. Also, the paper analyzes WWC, as it was the only other urban assessment tool found in the literature survey. In this sense, there are two categories of organizations in this paper: USGBC@, a NGO whose network of supporters is mostly related to the market, instead of public or academic agents (see Grazziano, 2019), and Bloomberg Philanthropies, a foundation with close ties to the public sector. Furthermore, the first deals mainly with environmental sustainability, while the latter does it in relation to better public administration performance.

No other systems were found dealing with the urban scale during the preliminary survey. LEED@ competitors as BREEAMO - a British environmental sustainability system -, DGNBC - a German one -, and CASBEE@ a Japanese initiative - have systems for neighborhoods but not cities. There was a North American system to assess cities, STARC, but it was acquired by USGBC@ and merged with its own product, LEEDC CC (Varnadore, 2018).

To analyze these systems, the paper uses geolocated data to understand how they are distributed in space. Also, it studies both the systems structure and a few case studies. It is also done a literature survey, both in scholar databases and grey literature. Scholar literature is conspicuously scarce, as these systems were recently launched (Dang et al., 2020; Rasca \& Waeben, 2019; Sharifi et al., 2020).

After this introduction, we present a discussion about urban science, as it is the theoretical framework in which these systems of urban assessment are grounded. The second section exposes a brief description of LEEDC CC and WWC. The third section discusses consequences of the systems' inclinations. At last, conclusions and the unfolding of this research are pointed out. Full data for the maps is attached to this paper. 


\section{SÃO PAULO15 17 LISBOA $25 \sim 26$ JUN 2020

\section{The urban science}

The urban science can be defined as "an interdisciplinary approach that practices and promotes a scientific and computational explanation of city systems and the processes of urbanization. It uses statistical analysis and data analytics - including machine learning, data mining, visual analytics, modelling and simulation - to identify casual relationships and predict how city systems work. In contrast to urban studies more generally, which views cities as constellations of places with analysis usually based upon fairly static empirical data (small samples, generated at specific places and times), urban science views cities as systems (or a system of systems) with analysis utilising urban big data (massive samples generated on a continuous basis)" (Kitchin, 2017, p. 2). In this sense, urban science presents an understanding of the city in real-time and highly detailed. It does not rely on suppositions and statistics, but in the de facto urban dynamic.

This can be a powerful tool in cities' management. Local managers would not need to respond to tendencies potentially outdated or fully established: they could perceive the city in real-time and provide solutions to problems that are still emerging. This could lead, then, to a more transparent and efficient administration of cities.

However, the assumption that the collected data rightfully describes an urban dynamic is debatable in its positivistic approach (Kitchin, 2017). The large sets of data available might induce managers to perceive this information as an accurate and non-biased portrait of a city, ignoring not only that data gathering itself may be biased, but also the non-quantitative aspects, as politics and culture (Morozov, 2018).

If the urban science is this new knowledge area employing big data, the "smart cities" are the spatial phenomena in which this epistemological approach takes place. The smart cities are the setting in which new technologies are applied in the everyday urban life. As such, these cities are conceived "as experimental locations in which to trial new technologies, architectures, and environmental-economic reforms is in large part linked to a quasi-utopian approach to the city as laboratory, as an empty and bounded container. This approach renders the physical environment of the city as a single site of intervention, and conceptualises the urban as a vessel of constrained socio-economic, environmental, and technological relations. When viewed as an experiment, the city can thus be reduced to a tabula rasa on which new technologies, transitional strategies, and other approaches can be tried and tested, and subsequently rolled out across wider scales." (Caprotti, 2014, p. 1286) Smart cities are then laboratories isolated in the urban network, in order to develop the technologies that will spread across the urban centers, as if these were "R\&D centres" (Joss et al., 2013, p. 72). They presuppose the idea that a "technological fix" is sufficient to solve the contemporary urban issues.

If the smart city is conceived as a laboratory, then it is inherently designed as an enclave. It is only in isolation that these innovations can be tested in practice, at the same time that they become showcases of the "smooth, unobstructed spaces" created (Bach, 2011; Caprotti, 2014, p. 1293). To do so, they are spatial enclaves, but also unequal settlements, as they require a highly controlled society to trial their technologies. Therefore, smart cities are conceived in agglomerations with higher income, instead of the impoverished areas more vulnerable to climate change and social inequality (Caprotti, 2014; Hodson \& Marvin, 2010).

The possibility of the smart city as a laboratory for technological products explains also the high influx of capital invested. Many smart cities are even directly designed by the private sector: Cisco, General Electric, Hitachi, IBM, and Panasonic are corporations that planned smart cities and eco-cities projects. There is only a restricted number of professionals able to develop these high complexity projects, which explains why there is 


\section{SÃOPAULO15 $17 \cdot$ LISBOA $25 \sim 26$ JUN 2020}

always the same network of international consultants and organizations working on them (Joss et al., 2013). The smart cities are, then, a new step in a long process producing capital-intensive urban spaces, the socalled "global cities", that share a restrict group of clients and designers (Arantes, 2000; Sassen, 1991).

The smart cities could then be read as a "corporate storytelling", a new corporate orientation toward data that should not be taken by its face value, as it promotes access to data and software, but indicates neither an interpretation nor a plan of action (Söderström et al., 2014). Hence, the smart city would be a new stage of the "entrepreneurial city" (Hollands, 2018) or of the "technoscientific urbanism" (Brenner \& Schmid, 2015; Greenfield, 2013; Townsend, 2013). Also, the smart city would be a neoliberal urban technology, as it reinforces the idea of the "audit culture" (Kipnis, 2008; Power, 1997), in which every aspect of the city can be synthetized in quantitative data. The level of access to data gets, then, a value of management transparency wherewith cities can be ranked, being at the same time a new market imperative for urban planners and administrators to pursue credit (Morozov \& Bria, 2018, p. 10) and an instrument of control (Shwayri, 2013; Vanolo, 2014).

\section{The systems of urban assessment}

Considering this debate regarding the urban science and its spatial manifestation in the smart cities, it is focused here a specific group of phenomena: the systems of assessment, specifically in the urban scale. These systems stand out as they not only evaluate the performance both of new and existing cities, but also award certifications to the better performing projects. Hence, these systems become disputed distinctions by cities that seek promotion for their policies in a global arena, being useful ways to attract further financial resources. The systems of assessment also become new products, as they promote themselves as useful tools to urban administration and look for increasing market share.

We will work on the two systems of assessment available for urban settings: What Works Cities (WWC) and LEEDC for Cities and Communities. Both systems were created by organizations that do not relate directly neither to the state nor to the market, configuring a distinctive feature of agents related to systems of assessment: the alignment to "the emerging urban-philanthrocapitalist complex of think-thanks, foundations, and allegedly neutral NGOs, determining the broader constraints and parameters within which cities now compete." (Morozov \& Bria, 2018, p. 9). Our argument is then that even if these systems have a technoscientific base, they hold specific standpoints regarding urban policy and design.

\subsection{What Works Cities (WWC)}

What Works Cities (WWC) is a program launched in April 2015 by Bloomberg Philanthropies, the foundation that gathers the charitable giving of the billionaire Michael R. Bloomberg. Its creation and management are shared with other organizations: the Behavioural Insights Team (BIT), the Center for Government Excellence (GovEx) at John Hopkins University, the Government Performance Lab at Harvard Kennedy School, Results for America, and the Sunlight Foundation. The program is devoted to help mid-sized cities, from 100,000 to one million citizens, using data to manage their issues and to make their decisions. Since its start, 103 cities are registered in the program, which represented an important vector of political support for Michael Bloomberg in his brief dispute for the Democrat nomination in the 2020 United States presidential election (Burns \& Kulish, 2020; Capps \& Holder, 2020). 



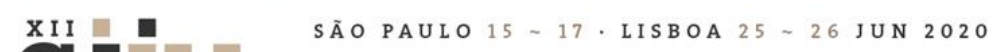

Seminário Internacional de Investigação em Urbanismo

Seminario Internacional de Investigación en Urbanismo

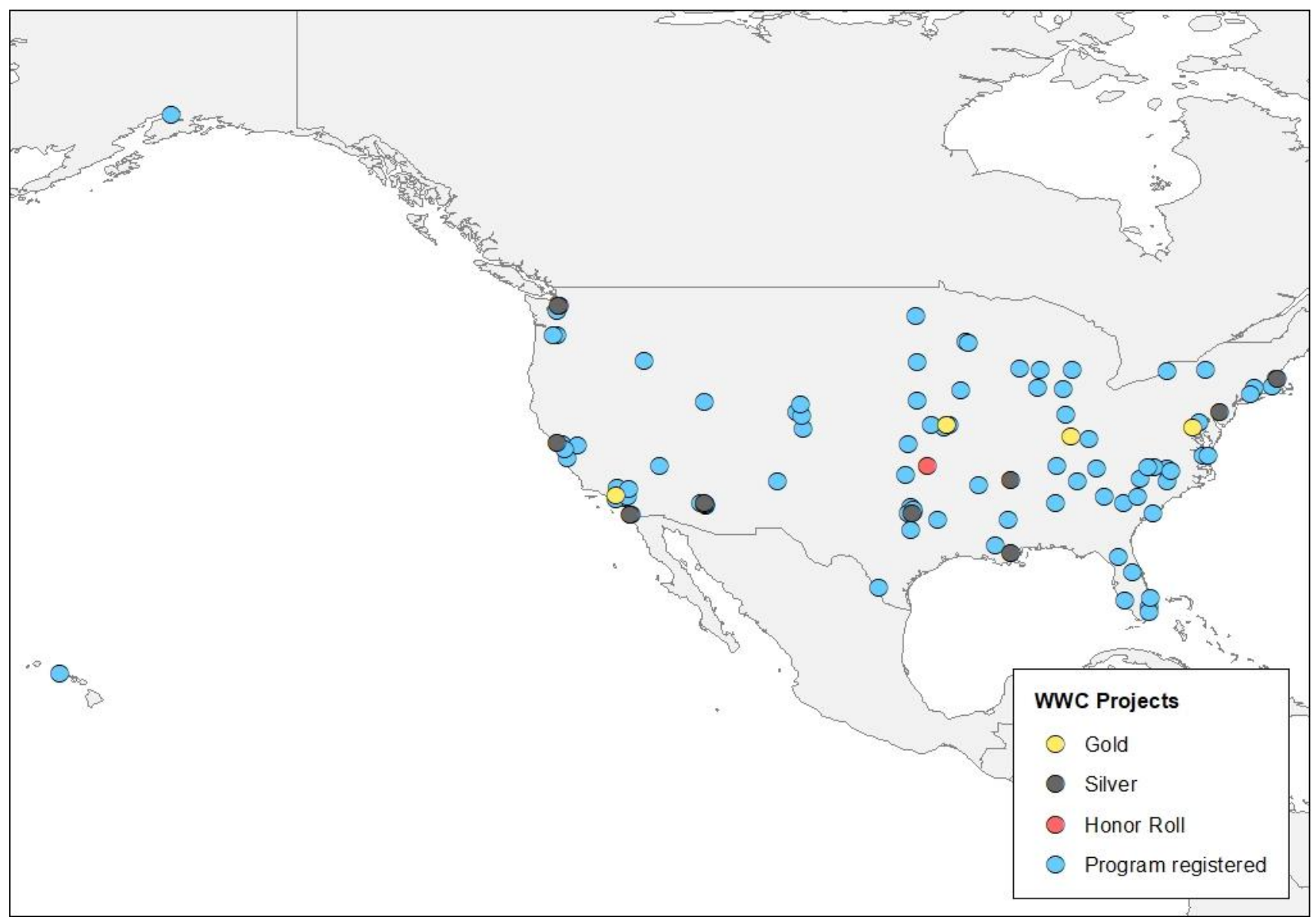

Fig. 01 What Works Cities projects. Own creation based on data from What Works Cities website, Feb $19^{\text {th }}, 2020$. Basemap: Natural Earth.

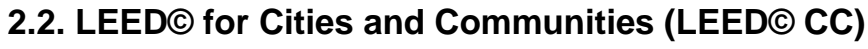

If WWC system is based on the previous urban governance program by Bloomberg Philanthropies, LEEDC for Cities and Communities (LEEDC CC) has closer ties to the built environment.

LEED@'s first version was launched in 1998 by US Green Building CouncilC, whose foundation was in 1993. It was dedicated exclusively to new construction, but the system has gradually expanded its scope of certification. LEEDC CC was launched in 2016 as part of a long-time USGBC@'s struggle to not be limited to the building and to respond to critics that viewed a lack of urban context in the system - a criticism that USGBC@'s CEO implicitly replies in a text (Ramanujam, 2019).

The total LEED $\odot$ CC's points is 110 , distributed in six main categories of assessment: Natural Systems \& Ecology (13 points), Transportation \& Land Use (18), Water Efficiency (12), Energy \& Greenhouse Gas Emissions (31), Materials \& Resources (11), and Quality of Life (10), as well as minor categories as Innovation (6) and Regional Priority (4), and two credits outside all categories (5). Each category has its own 


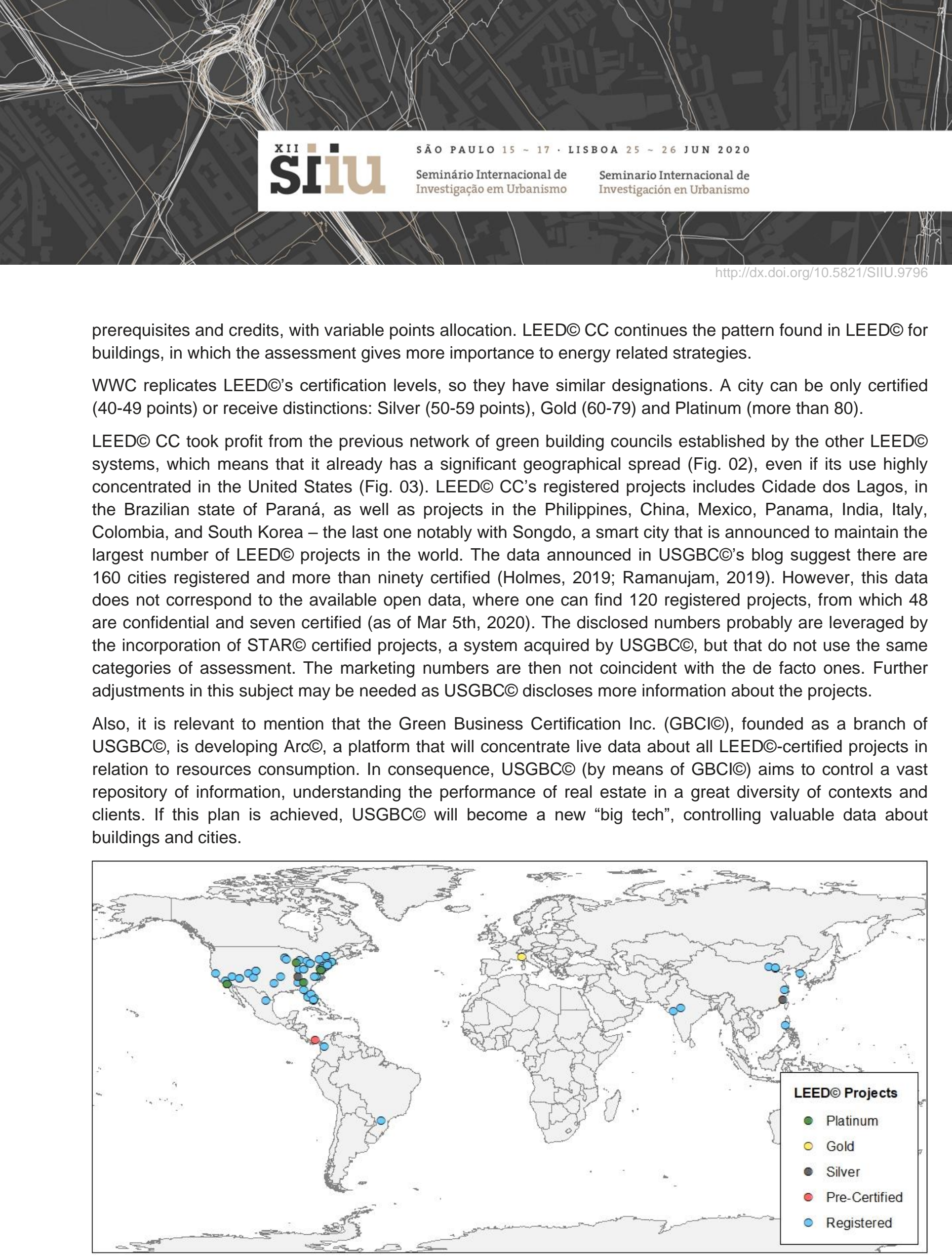

Fig. 02 LEEDC for Cities and Communities projects. Own creation based on data from LEED Project Directory, Mar $5^{\text {th }}, 2020$. Basemap: Natural Earth. 


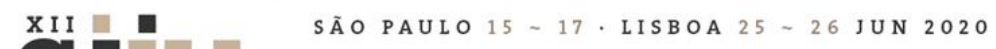

Seminário Internacional de Investigação em Urbanismo

Seminario Internacional de Investigación en Urbanismo

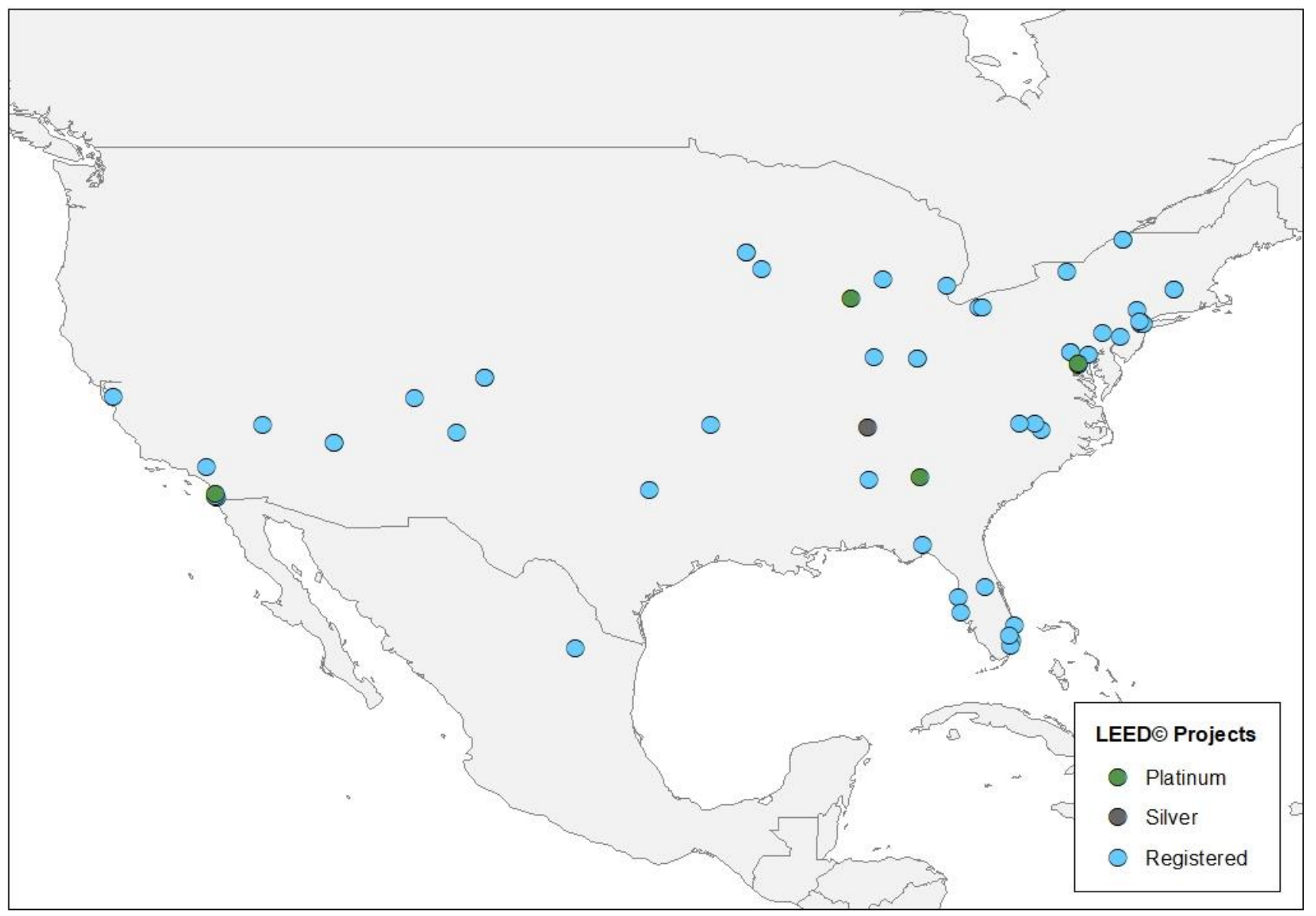

Fig. 03 LEED@ for Cities and Communities projects, emphasis in United States. Own creation based on data from LEED Project Directory, Mar $5^{\text {th }}, 2020$. Basemap: Natural Earth.

\section{Discussion}

The diverse emphasis of each system is marked, as WWC assesses mostly the gathering and management of urban data in order to carry out policies, while LEEDC uses metrics for environmental sustainability and well-being. Some cities are registered in both systems, reflecting an effort to apply to multiple certifications and supports: Arlington, TX; Baltimore, MD; Birmingham, AL; Cary, NC; Chula Vista, CA; Fayetteville, AR; Lewisville, TX; Louisville, KY; Miami, FL; Orlando, FL; Rancho Cucamonga, CA; Saint Paul, MN; San Diego, CA; San Jose, CA; Washington, DC; and West Palm Beach, FL.

Both systems rely heavily on process and management instead of clear results and morphological impact on cities. This is relevant, as they can be applied to reasonably different urban forms and geographical contexts. LEEDC CC has some impact on urban design by indicating a few parameters, as street width ("TR: Walkability and Bikeability") and mass transit shelters ("TR: Access to Quality Transit"), but it is minimal if one compares to other LEED@ systems (Grazziano, 2019). 


\section{SÃOPAULO15 $17 \cdot$ LISBOA $25 \sim 26$ JUN 2020}

However, this emphasis on process and diversity of applications may conceal contradictory results. The scorecards of each project are not yet available, which means that this interpretation might change. But it must be noted that rational management process may lead to irrational or inefficient results (Drori et al., 2006). There is a large set of credits available to the candidates' judgement, leading to a choice based on easiness rather than palpable sustainability or efficiency. Also, some credits have excessively modest requirements: One example is LEED@ CC's pre-requisite "QL: Social Infrastructure", which demands meeting only the already existing codes and regulations. Both situations - abundance of options and low requirements - were noted in analysis made by the literature about LEEDC (Brown, 2010; Yudelson, 2016), whose alerts continue valid to the systems of urban assessment studied here.

Some examples of LEEDC registered projects can elucidated these problems. The Brazilian Cidade dos Lagos may have an efficient employment of infrastructure, but it replicates the Brazilian morphological pattern of real-estate products in mid-sized cities. It is a suburban enclave, formed by a middle class low-density residential settlement and a shopping mall, in an area that until very recently had fertile soil and was assigned for soybean and eucalyptus crops (Abdalla, 2017). Another example is Songdo, promoted as a smart global city, but that lacks everyday urban life and density, albeit the high investments being made (Poon, 2018). Despite their different contexts, both expect to receive high influx of capital and investors, which the model of certifications help to assure (Faulconbridge \& Yalciner, 2015).

While focusing on the urban, these systems have few impacts on urban form, preferring to engage in urban administration. At the same time, WWC@ and LEEDC CC have liberal foundations, opting to not determine how governance should be done, but to establish guidelines for the managing process. - a position that can be traced to other systems, as ISO (Easterling, 2014). These guidelines can be rather vague, as the diversity of credits may be only partially accomplished, following the candidate's preference.

\section{Conclusions}

Data so far gathered points out that cities using systems of urban assessment may need access to financial resources since the beginning of their plans (Brody et al., 2016), and that the systems fail to restrict the certified cities to really prominent solutions. Somewhat typical projects are certified, leading to higher financial and advertising appeal, even though the certifications concern process more than results.

It should be noted though that the same transparency expected from public agents and evaluated in these systems should be applied to the systems themselves. There is not open and large-scale data about the registered and certified cities; there is no open scorecards or evaluation reports disclosed. In this sense, the certifications cannot be accurately assessed, as it is not possible to know for which credits each project applied, which ones were granted, and how the projects performed and demonstrated performance on them. Transparency should be pursued by all agents in urban management: by public institutions that decide plans that impact far-reaching areas and citizens, but also by the systems that assess those plans - otherwise we might create new "big techs" privately controlling our urban data and knowledge. 


\section{XII $\quad$ SÃOPAULO $15 \sim 17 \cdot$ LISBOA $25 \sim 26$ JUN 2020}

\section{REFERENCES}

ARANTES, Otilia Beatriz Fiori. (2000). Uma estratégia fatal: A cultura nas novas gestões urbanas. In O.B.F. ARANTES, E. MARICATO, \& C. VAINER, A cidade do pensamento único: Desmanchando consensos (2nd ed, p. 11-74). Vozes.

$\mathrm{BACH}$, J. (2011). Modernity and the urban imagination in economic zones. Theory, Culture \& Society, 28(5), 98-122. https://doi.org/10.1177/0263276411411495

BECK, U. (2005). Power in the global age: A new global political economy. Polity Press.

BOLI, J., \& THOMAS, G. M. (1999). Constructing world culture: International nongovernmental organizations since 1875. Stanford University Press.

BRENNER, N., \& SCHMID, C. (2015). Towards a new epistemology of the urban? City, 19(2-3), 151-182. https://doi.org/10.1080/13604813.2015.1014712

BRODY, S., KOESTER, A., MARKOVITS, Z., \& PHILIPS, J. (2016). Moving the needle: What Works Cities and the use of data and evidence. Bloomberg Data for Good Exchange Conference.

BROWN, M. F. (2010). A tale of three buildings: Certifying virtue in the new moral economy. American Ethnologist, 37(4), 741-752. https://doi.org/10.1111/j.1548-1425.2010.01282.x

BURNS, A., \& KULISH, N. (2020, February 15th). Bloomberg's billions: How the candidate built and empire of influence. The New York Times.

CAPROTTI, F. (2014). Eco-urbanism and the eco-city, or, denying the right to the city? Antipode, 46(5), 12851303. https://doi.org/10.1111/anti.12087

CASTELLS, M. (2010). The information age: Economy, society, and culture: Vol. II: The power of identity (2nd [Ed. orig.: 1997]). Wiley-Blackwell.

CHAUÍ, M. (2003). A universidade pública sob nova perspectiva. Revista Brasileira de Educação, 24, 5-15.

DANG, X., ZHANG, Y., FENG, W., ZHOU, N., WANG, Y., MENG, C., \& GINSBERG, M. (2020). Comparative study of city-level sustainability assessment standards in China and the United States. Journal of Cleaner Production, 251. https://doi.org/10.1016/j.jclepro.2019.119622

DRORI, G. S., MEYER, J. W., \& HWANG, H. (Orgs.). (2006). Globalization and organization: World society and organizational change. Oxford University Press.

EASTERLING, K. (2014). Extrastatecraft: The power of infrastructure space. Verso.

FAULCONBRIDGE, J., \& YALCINER, S. (2015). Local variants of mobile sustainable building assessment models: The marketization and constrained mutation of BREEAM ES. Global networks, 15, 360-378. https://doi.org/10.1111/glob.12083

GRAZZIANO, R. (2019). Virtualidades e contradições no espaço sob padrões globais: LEED® e arquitetura corporativa em São Paulo. PhD Thesis on History and Tenets of Architecture and Urbanism. Supervisor: Luiz Recamán, Faculty of Architecture and Urbanism of the University of São Paulo. https://doi.org/10.11606/T.16.2019.tde-11122019-122755 


\section{SÃO PAULO15 17 LISBOA $25 \sim 26$ JUN 2020}

GREENFIELD, A. (2013). Against the smart city. Do Projects.

HODSON, M., \& MARVIN, S. (2010). Urbanism in the anthropocene: Ecological urbanism or premium ecological enclaves? City, 14(3), 298-313. https://doi.org/10.1080/13604813.2010.482277

HOLLANDS, R. G. (2018). Will the real smart city please stand up? Intelligent, progressive or entrepreneurial? City, 12(3), 303-320. https://doi.org/10.1080/13604810802479126

JOSS, S., COWLEY, R., \& TOMOZEIU, D. (2013). Towards the 'ubiquitous eco-city': An analysis of the internationalisation of eco-city policy and practice. Urban Research \& Practice, 6(1), 54-74. https://doi.org/10.1080/17535069.2012.762216

KIPNIS, A. P. (2008). Audit cultures: Neoliberal governmentality, socialist legacy, or technologies of governing? American Ethnologist, 35(2), 275-289. https://doi.org/10.1111/j.2008.1548-1425.00034.x

KITCHIN, R. (2017). Urban science: A short primer. The Programmable City, Working Paper 23. http://progcity.maynoothuniversity.ie/

MOROZOV, E. (2018). Efeitos colaterais dos algoritmos para a cultura democrática. In Big Tech: A ascensão dos dados e a morte da política (p. 138-143). Ubu.

MOROZOV, E., \& BRIA, F. (2018). Rethinking the smart city: Democratizing urban technology. Rosa Luxemburg Stiftung.

POWER, M. (1997). The audit society: Rituals of verification. Oxford University Press.

RASCA, S., \& WAEBEN, J. (2019). Sustainable Development of Small and Medium Sized Cities: Use of Monitoring Frameworks in Reaching the SDGs. 2019 Smart City Symposium Prague (SCSP), 1-6. https://doi.org/10.1109/SCSP.2019.8805693

SASSEN, S. (1991). The global city: New York, London, Tokyo. Princeton University Press.

SHARIFI, A., KAWAKUBO, S., \& MILOVIDOVA, A. (2020). Urban sustainability assessment tools: Toward integrating smart city indicators. In Y. YAMAGATA \& P. P. J. YANG (Orgs.), Urban systems design: Creating sustainable smart cities in the internet of things era (p. 345-372). Elsevier. https://doi.org/10.1016/B978-0-12816055-8.00011-7

SHWAYRI, S. T. (2013). A model Korean ubiquitous eco-city? The politics of making Songdo. Journal of Urban Technology, 20(1), 39-55. https://doi.org/10.1080/10630732.2012.735409

SÖDERSTRÖM, O., PAASCHE, T., \& KLAUSER, F. (2014). Smart cities as corporate storytelling. City, 8(3), 307-320. https://doi.org/10.1080/13604813.2014.906716

TOWNSEND, A. M. (2013). Smart Cities: Big data, civic hackers, and the quest for a new utopia. W.W. Norton \& Company.

VANOLO, A. (2014). Smartmentality: The Smart City as Disciplinary Strategy. Urban Studies, 51(5), 883-898.

WILSON, S., \& LILLY, A. (2016). Bloomberg Philanthropies - What Works Cities. Case study. Institute for Government. 


\section{XII $\mathbf{E}$ SÃO PAULO $15 \sim 17 \cdot$ LISBOA $25 \sim 26$ JUN 2020}

YUDELSON, J. (2016). Reinventing green building: Why certification systems aren't working and what we can do about it. New Society Publishers.

\section{Electronic resources}

ABDALLA, S. (2017, August 21st). Com investimento milionário, cidade do PR ganha megabairro com lago, cinema e parque de diversões. Gazeta do Povo. https://www.gazetadopovo.com.br/haus/imoveis/cominvestimento-milionario-cidade-do-pr-ganha-megabairro-com-lago-cinema-e-parque-de-diversoes/?ref=linkinterno-materia (Accessed: 06/03/2020).

CAPPS, K., \& HOLDER, S. (2020, February 3rd). The presidential candidates that mayors support. CityLab. https://www.citylab.com/equity/2020/02/2020-presidential-election-candidates-mayor-endorsements/605797/ (Accessed: 06/03/2020).

HOLDER, S. (2019, June 18th). The 10 cities getting a philanthropic boost for economic mobility. CityLab. https://www.citylab.com/equity/2019/06/bloomberg-philanthropy-economic-mobility-newark-rochester/591790/ (Accessed: 06/03/2020).

HOLMES, S. (2019, June 6th). LEED for Cities and Communities around the world: June 2019. USGBC. https://www.usgbc.org/articles/leed-cities-and-communities-around-world-june-2019 (Accessed: 06/03/2020).

POON, L. (2018, June 22nd). Sleepy in Songdo, Korea's smartest city. CityLab. https://www.citylab.com/life/2018/06/sleepy-in-songdo-koreas-smartest-city/561374/ (Accessed: 06/03/2020).

RAMANUJAM, M. (2019, August 1st). The evolution of LEED for Cities and Communities. USGBC. https://www.usgbc.org/articles/evolution-leed-cities-and-communities (Accessed: 06/03/2020).

VARNADORE, H. (2018, October 15th). STAR's merger with USGBC. Star Communities. http://www.starcommunities.org/star-updates/faqs-star-leed-for-cities/ (Accessed: 06/03/2020).

WHAT Works Cities. (2018, January 25th). Meet the What Works Cities Certification Standard Committee. Medium. https://medium.com/what-works-cities-certification/meet-the-what-works-cities-certification-standardcommittee-524ed1394c74 (Accessed: 06/03/2020). 


\section{Appendix I - WWC Projects}

\begin{tabular}{|c|c|c|c|c|}
\hline$\#$ & City & State & Certification Level & Year \\
\hline 1 & Albuquerque & NM & Program registered & \\
\hline 2 & Anchorage & $\mathrm{AK}$ & Program registered & \\
\hline 3 & Arlington & $\mathrm{TX}$ & Silver & 2019 \\
\hline 4 & Athens & $\mathrm{GA}$ & Program registered & \\
\hline 5 & Augusta & $\mathrm{GA}$ & Program registered & \\
\hline 6 & Baltimore & MD & Program registered & \\
\hline 7 & Baton Rouge & LA & Program registered & \\
\hline 8 & Bellevue & WA & Honor Roll & \\
\hline 9 & Birmingham & $A L$ & Program registered & \\
\hline 10 & Boise & ID & Program registered & \\
\hline 11 & Boston & MA & Silver & 2018 \\
\hline 12 & Boulder & $\mathrm{CO}$ & Program registered & \\
\hline 13 & Buffalo & NY & Program registered & \\
\hline 14 & Cambridge & MA & Program registered & \\
\hline 15 & Cape Coral & $\mathrm{FL}$ & Program registered & \\
\hline 16 & Cary & $\mathrm{NC}$ & Program registered & \\
\hline 17 & Charleston & $\mathrm{SC}$ & Program registered & \\
\hline 18 & Charlotte & NC & Program registered & \\
\hline 19 & Chattanooga & $\mathrm{TN}$ & Program registered & \\
\hline 20 & Chula Vista & $\mathrm{CA}$ & Program registered & \\
\hline 21 & $\begin{array}{l}\text { Colorado } \\
\text { Springs }\end{array}$ & $\mathrm{CO}$ & Program registered & \\
\hline 22 & Columbia & SC & Program registered & \\
\hline 23 & Corona & $\mathrm{CA}$ & Program registered & \\
\hline 24 & Denton & $\mathrm{TX}$ & Program registered & \\
\hline 25 & Denver & $\mathrm{CO}$ & Program registered & \\
\hline 26 & Des Moines & IA & Program registered & \\
\hline 27 & Downey & $\mathrm{CA}$ & Program registered & \\
\hline 28 & Durham & $\mathrm{NC}$ & Program registered & \\
\hline 29 & Fargo & ND & Program registered & \\
\hline 30 & Fayetteville & NC & Program registered & \\
\hline 31 & Fort Collins & $\mathrm{CO}$ & Program registered & \\
\hline 32 & $\begin{array}{l}\text { Fort } \\
\text { Lauderdale }\end{array}$ & $\mathrm{FL}$ & Program registered & \\
\hline 33 & Fort Worth & $\mathrm{TX}$ & Program registered & \\
\hline 34 & Gainesville & $\mathrm{FL}$ & Program registered & \\
\hline 35 & Gilbert & $A Z$ & Program registered & \\
\hline 36 & Glendale & $A Z$ & Program registered & \\
\hline 37 & Grand Rapids & MI & Program registered & \\
\hline
\end{tabular}

\begin{tabular}{|c|c|c|c|c|}
\hline$\#$ & City & State & Certification Level & Year \\
\hline 38 & Greensboro & NC & Program registered & \\
\hline 39 & Gresham & OR & Program registered & \\
\hline 40 & Hartford & $\mathrm{CT}$ & Program registered & \\
\hline 41 & Hayward & $\mathrm{CA}$ & Program registered & \\
\hline 42 & Honolulu & $\mathrm{HI}$ & Program registered & \\
\hline 43 & Independence & MO & Program registered & \\
\hline 44 & Indianapolis & IN & Program registered & \\
\hline 45 & Irving & TX & Program registered & \\
\hline 46 & Jackson & MS & Program registered & \\
\hline 47 & Kansas City & KS & Program registered & \\
\hline 48 & Kansas City & MO & Gold & 2019 \\
\hline 49 & Knoxville & $\mathrm{TN}$ & Program registered & \\
\hline 50 & Laredo & TX & Program registered & \\
\hline 51 & Las Vegas & NV & Program registered & \\
\hline 52 & Lewisville & $\mathrm{TX}$ & Program registered & \\
\hline 53 & Lexington & KY & Program registered & \\
\hline 54 & Lincoln & NE & Program registered & \\
\hline 55 & Little Rock & $\mathrm{AR}$ & Program registered & \\
\hline 56 & Long Beach & $\mathrm{CA}$ & Program registered & \\
\hline 57 & Louisville & KY & Gold & 2019 \\
\hline 58 & Madison & WI & Program registered & \\
\hline 59 & Memphis & TN & Silver & 2019 \\
\hline 60 & Mesa & $A Z$ & Program registered & \\
\hline 61 & Miami & $\mathrm{FL}$ & Program registered & \\
\hline 62 & Milwaukee & WI & Program registered & \\
\hline 63 & Minneapolis & MN & Program registered & \\
\hline 64 & Modesto & $\mathrm{CA}$ & Program registered & \\
\hline 65 & Naperville & IL & Program registered & \\
\hline 66 & Nashville & $\mathrm{TN}$ & Program registered & \\
\hline 67 & New Haven & CT & Program registered & \\
\hline 68 & New Orleans & LA & Silver & 2018 \\
\hline 69 & Norfolk & VA & Program registered & \\
\hline 70 & Oklahoma City & OK & Program registered & \\
\hline 71 & Olathe & KS & Program registered & \\
\hline 72 & Orlando & $\mathrm{FL}$ & Program registered & \\
\hline 73 & Palmdale & $\mathrm{CA}$ & Program registered & \\
\hline 74 & Portland & OR & Program registered & \\
\hline
\end{tabular}




\section{SÃO PAULO15 17 LISBOA $25 \sim 26$ JUN 2020}

Seminário Internacional de Seminario Internacional de Investigação em Urbanismo Investigación en Urbanismo

\begin{tabular}{lllll}
\hline$\#$ & City & State & Certification Level & Year \\
\hline 75 & Providence & RI & Program registered & \\
\hline 76 & Raleigh & NC & Program registered & \\
77 & Rancho & CA & Program registered & \\
78 & Riverside & CA & Program registered & \\
79 & Saint Paul & MN & Program registered & \\
80 & Salinas & CA & Program registered & \\
81 & Salt Lake City & UT & Program registered & \\
82 & San Francisco & CA & Silver & \\
83 & San Jose & CA & Program registered & \\
84 & Scottsdale & AZ & Silver & \\
85 & Seattle & WA & Silver & \\
86 & Sioux Falls & SD & Program registered & \\
87 & South Bend & IN & Program registered & \\
88 & Syracuse & NY & Program registered & \\
89 & Tacoma & WA & Program registered & \\
\hline
\end{tabular}

\begin{tabular}{|c|c|c|c|c|}
\hline$\#$ & City & State & Certification Level & Year \\
\hline 90 & Tempe & $A Z$ & Program registered & \\
\hline 91 & Topeka & KS & Program registered & \\
\hline 92 & Tulsa & OK & Honor Roll & \\
\hline 93 & Tyler & $\mathrm{TX}$ & Program registered & \\
\hline 94 & Victorville & $\mathrm{CA}$ & Program registered & \\
\hline 95 & Virginia Beach & VA & Program registered & \\
\hline 96 & Waco & $\mathrm{TX}$ & Program registered & \\
\hline 97 & Washington & $\mathrm{DC}$ & Gold & 2019 \\
\hline 98 & $\begin{array}{l}\text { West Palm } \\
\text { Beach }\end{array}$ & $\mathrm{FL}$ & Program registered & \\
\hline 99 & Wichita & KS & Program registered & \\
\hline 100 & Winston-Salem & $\mathrm{NC}$ & Program registered & \\
\hline 101 & Los Angeles & $\mathrm{CA}$ & Gold & 2018 \\
\hline 102 & Philadelphia & PA & Silver & 2019 \\
\hline 103 & San Diego & $\mathrm{CA}$ & Silver & 2018 \\
\hline
\end{tabular}

\section{Appendix II - LEEDC CC Projects}

\begin{tabular}{|c|c|c|c|c|c|c|c|c|c|}
\hline$\#$ & Project & Country & Level & Date & $\#$ & Project & Country & Level & Date \\
\hline 1 & Newark, NJ & USA & Registered & & 18 & The Sky Castle In & China & Silver & 2019 \\
\hline 2 & Newark, NJ & USA & Registered & & 19 & $\begin{array}{l}\text { Kuliang } \\
\text { The New York }\end{array}$ & USA & Registered & \\
\hline 3 & $\begin{array}{l}\text { Songdo } \\
\text { International }\end{array}$ & $\begin{array}{l}\text { South } \\
\text { Korea }\end{array}$ & Registered & & 20 & $\begin{array}{l}\text { Olympic Region } \\
\text { San Jose }\end{array}$ & USA & Registered & \\
\hline 4 & $\begin{array}{l}\text { Business District } \\
\text { Schenectady }\end{array}$ & USA & Registered & & 21 & Bloomington & USA & Registered & \\
\hline 5 & Savonna & Italy & Gold & 2018 & 22 & $\begin{array}{l}\text { Testskoru - } \\
\text { Sinziana Rasca }\end{array}$ & USA & Registered & \\
\hline 6 & Rochester, MN & USA & Registered & & 23 & Durango & USA & Registered & \\
\hline 7 & Destination & USA & Registered & & 24 & Oldsmar & USA & Registered & \\
\hline 8 & $\begin{array}{l}\text { Medical Center } \\
\text { HJAIA Airport }\end{array}$ & USA & Platinum & 2019 & 25 & Reading & USA & Registered & \\
\hline 9 & Beijing Daxing & China & Registered & & 26 & Cleveland & USA & Registered & \\
\hline & International & & & & 27 & Cary & USA & Registered & \\
\hline 10 & $\begin{array}{l}\text { Airport Eco } \\
\text { Surat }\end{array}$ & India & Registered & & 28 & Hollywood & USA & Registered & \\
\hline 11 & Arlington County, & USA & Platinum & 2017 & 29 & Birmingham & USA & Registered & \\
\hline & & & & & 30 & Holland & USA & Registered & \\
\hline 12 & Chicago & USA & Platinum & 2018 & 31 & Orange County & USA & Registered & \\
\hline 13 & Hoboken & USA & Registered & & 32 & Fayetteville & USA & Registered & \\
\hline 14 & San Diego & USA & Platinum & 2018 & 33 & Northampton & USA & Registered & \\
\hline 15 & Indore Smart City & India & Registered & & 34 & Louisville & USA & Registered & \\
\hline 16 & Ciudad del Saber & Panama & Pre-Certified & 2018 & 35 & Lewisville, TX & USA & Registered & \\
\hline 17 & Franklin, TN & USA & Silver & 2018 & & & & & \\
\hline
\end{tabular}




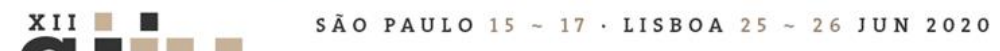

Seminário Internacional de Seminario Internacional de Investigação em Urbanismo Investigación en Urbanismo

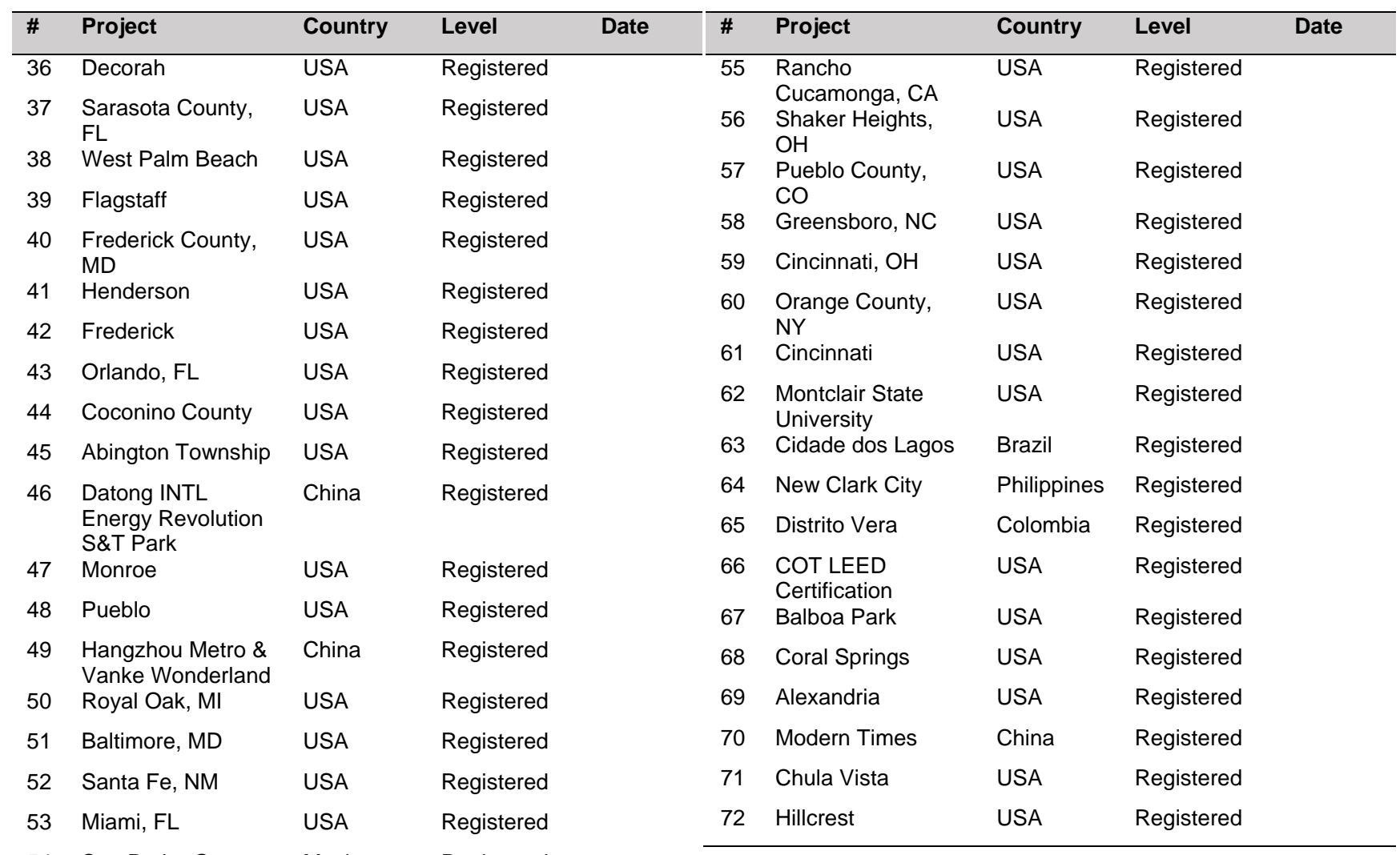

54 San Pedro Garza Mexico Registered Garcia 